\title{
DETERMINATION OF BEESWAX HYDROCARBONS BY GAS CHROMATOGRAPHY WITH A MASS DETECTOR (GC-MS) TECHNIQUE
}

\author{
Ewa Waś* \\ Teresa Szczęsna \\ Helena Rybak-Chmielewska \\ Research Institute of Horticulture, Apiculture Division, \\ Kazimierska 2, 24-100 Puławy, Poland \\ *corresponding author: ewa.was@inhort.pl \\ Received 14 April 2014; accepted 12 May 2014
}

A b s t r a c t

Here we describe a method of hydrocarbon (alkanes, alkenes, dienes) identification and quantitative determination of linear saturated hydrocarbons ( $n$-alkanes) in beeswax using gas chromatography with a mass detector technique (GC-MS). Beeswax hydrocarbons were isolated using a solid-phase extraction (SPE) technique with neutral aluminum oxide (Alumina - N, $1000 \mathrm{mg}, 6 \mathrm{~mL}$ ), then were separated on a non-polar gas chromatography column ZB-5HT INFERNO $(20 \mathrm{~m} \times 0.18 \mathrm{~mm} \times 0.18 \mu \mathrm{m})$. Qquantitative analysis of $\mathrm{n}$-alkanes was conducted by the method of internal standard with squalane used as the internal standard. The basic parameters of validation (linearity and working range, limit of determination, repeatability and reproducibility, recovery) were determined. For all of the identified compounds, satisfactory ( $\geq 0.997)$ coefficients of correlation in the working ranges of the method (from 0.005 to $5.0 \mathrm{~g} / 100 \mathrm{~g}$ ) were obtained. The elaborated method was characterized by satisfactory repeatability and within-laboratory reproducibility. The average coefficients of variation for the total n-alkanes did not exceed $2 \%$ under conditions of repeatability or $4 \%$ under conditions of reproducibility. The recovery for individual $n$-alkanes was above $94 \%$; for their total content, it was $100.5 \%$. In beeswax originating from Apis mellifera, $\mathrm{n}$-alkanes containing from 20 to 35 carbon atoms in their molecules were determined. The total content of these alkanes was between $9.08 \mathrm{~g}$ and $10.86 \mathrm{~g} / 100 \mathrm{~g}$ (on average, $9.81 \mathrm{~g} / 100 \mathrm{~g}$ ). Additionally, apart from the saturated hydrocarbons, unsaturated hydrocarbons and dienes were identified.

Keywords: beeswax, GC-MS, hydrocarbons, n-alkanes, SPE.

\section{INTRODUCTION}

Beeswax is a wax gland secretion of bee workers. The wax glands show the greatest activity in bees from 9 to 15 days old, but depending on the needs of the bee colony, wax can produce the bees slightly younger or much older (Skowronek, 1973). Chemically, it is a complex mixture of compounds, of which over 300 have been identified so far. Beeswax components fall into the following chemical groups: esters (67\%), hydrocarbons (14\%), fatty acids (12\%), and alcohols (1\%) (Tulloch, 1980). Among the hydrocarbons, the most numerous group are linear saturated hydrocarbons (n-alkanes), accounting for ca. $67 \%$ of all hydrocarbons occurring in beeswax; branched alkanes occur in much smaller amounts $(0.2 \%)$. Apart from saturated hydrocarbons, unsaturated hydrocarbons containing one double bond (alkenes) can also be found in beeswax (Streibl et al., 1966). Furthermore, some authors (Giumanini et al., 1995; Aichholz and Lorbeer, 1999, 2000; Jimenez et al., 2004) indicate the presence of dienes, unsaturated hydrocarbons with two double bonds.

Beeswax is mainly used in beekeeping to produce the comb foundation. However, this product is also widely used in chemical, cosmetic, pharmaceutical, and food industries, among others. It is registered in the EU under the symbol E901 (EFSA, 2007).

Because beeswax is quite frequently adulterated with cheaper hydrocarbons of alien origin, it is necessary to be able to perform accurate qualitative and quantitative analysis of beeswax hydrocarbons. Many methods used so far for determination of hydrocarbons in beeswax and of beeswax adulteration have been based on physico-chemical parameters, such as melting point, density, solubility, and sa- 
ponification, acid and ester values, and iodine index (Tulloch, 1973; Serra Bonvehi et al., 1989; Serra Bonvehi, 1990; Vit et al., 1992; Poncini et al., 1993). Those methods, although still used in the evaluation of beeswax quality (Bogdanov, 2004; Bernal et al., 2005; Serra Bonvehi and Ornantes Bermejo, 2012; Maia and Nunes, 2013), are not very accurate and often require verification with chromatographic methods.

Chromatography allows separation and determination of individual components of beeswax. In the 1950s and 1960s, aluminum oxide and silica gel, among others, were used to separate different groups of beeswax compounds (Sprengler and Wöllner, 1953, 1954; Fusch and de Jong, 1954; Curyło and Zalewski, 1957a, b; Curyło and Ignaszewska, 1969). Column chromatography combined with weight analysis is still recommended in the domestic standards for beeswax (DGF-M-V-6, 1957; PN-R78890, 1996). This technique does not, however, allow for identification of individual compounds but only for determination of their quantity; thus, it is impossible to characterize hydrocarbons and other beeswax constituents accurately.

The study of the composition of beeswax became possible with the advent of gas chromatography techniques. This method was used for the first time for the analysis of beeswax hydrocarbons by White et al. (1960) and Downing et al. (1961). Gas chromatography with different kinds of detection (FID, MS) is now commonly used in studies of beeswax composition (Aichholz and Lorbeer, 1996, 1999, 2000; Jimenez et al., 2003, 2004, 2006, 2007, 2009; Serra Bonvehi and Ornantes Bermejo, 2012; Maia and Nunes, 2013), and the majority of compounds belonging to certain homologous series have been characterized. However, some beeswax constituents remain unknown despite the use of the most recent chromatography techniques. Analysts encounter considerable difficulties when studying isomers because in many cases, it is impossible to find the location of the unsaturated bonds. Some problems with the quantitative analysis of individual compounds can be noted in the majority of the above-reported works, including difficulties with determining hydrocarbon content, which is particularly meaningful when detecting beeswax adulterations. The study aim was to develop a method of hydrocarbon identification (alkanes, alkenes, dienes) and quantitative determination of n-alkanes in beeswax using gas chromatography with a mass detector (GC-MS) technique.

\section{MATERIAL AND METHODS}

\section{Reagents}

The analytical standard mixtures of $n$-alkanes $\left(\mathrm{C}_{8} \mathrm{H}_{18}-\mathrm{C}_{20} \mathrm{H}_{42}\right.$ and $\left.\mathrm{C}_{21} \mathrm{H}_{44}-\mathrm{C}_{40} \mathrm{H}_{82}\right)$ were obtained from Fluka (Buchs, Switzerland; Saint Louis, MO, USA). A standard mixture of n-alkanes from $\mathrm{C}_{10} \mathrm{H}_{22}$ to $\mathrm{C}_{35} \mathrm{H}_{72}$ was provided by Dr. Ehrenstorfer (Augsburg, Germany). Squalane (99.9\% purity) from Supelco (Bellefonte, PA, USA) was used as an internal standard.

Hexane SupraSolv ${ }^{\circledast}$ for gas chromatography $(\geq 98 \%$ purity) was obtained from Merck (Darmstadt, Germany), and heptane anhydrous ( $298.5 \%$ purity) was from Sigma-Aldrich (Steinheim, Germany). Solidphase extraction (SPE) cartridges filled with neutral aluminum oxide (Alumina - N, $1000 \mathrm{mg}, 6 \mathrm{~mL}$ ) were purchased from Agela Technologies (Wilmington, DE, USA). Helium (99.9999\% purity) was provided by Air Products (Warsaw, Poland).

\section{Beeswax samples}

The experimental material comprised samples of beeswax ( $n=7$ ) originating from Apis mellifera, obtained from light combs (so-called "virgin wax"). The beeswax samples were collected in the years 2007 - 2008 at apiaries of the Apiculture Division in Puławy.

The pieces of beeswax combs were melted in a drier at a temperature of $70-75^{\circ} \mathrm{C}$ and purified on a filter made of gauze. Homogenized and free from mechanical impurities, beeswax samples were kept in a dry, cool, and dark place until further analysis.

\section{Sample preparation}

Following addition of $7.5 \mathrm{~mL}$ of heptane to the beeswax sample $(0.05 \pm 0.001 \mathrm{~g})$, the sample was shaken at $50^{\circ} \mathrm{C}$ for about 12 min until the beeswax dissolved. After cooling of the solution, $2.5 \mathrm{~mL}$ of squalane at $400 \mathrm{mg} / \mathrm{L}$ was added. Then, the beeswax hydrocarbons were isolated using SPE with columns filled with neutral aluminum oxide. The procedure of hydrocarbon extraction from beeswax with the SPE method is shown in Figure 1. Finally, the eluate (hydrocarbon fraction) was collected into a $10 \mathrm{~mL}$ flask, which was filled to a certain volume with heptane. The solution then was transferred to the autosampler vial and chromatography analysis carried out.

\section{Screening of beeswax hydrocarbons with the GC-MS technique}

A gas chromatograph with mass detector (GCMS - QP2010 Plus) manufactured by Shimadzu was used to develop a method for the determination 
a)

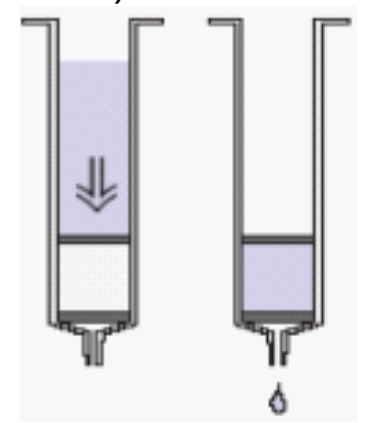

b)

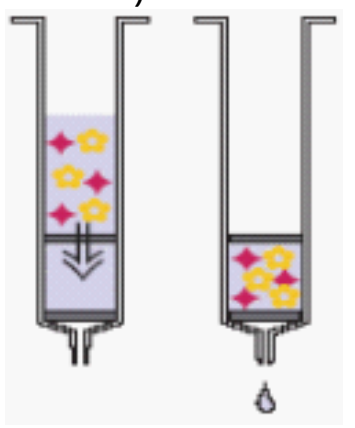

c)

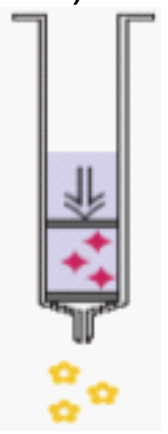

hydrocarbons

interfering compounds (e.g., esters)

Fig. 1. Extraction of hydrocarbons from beeswax with the SPE technique

a) conditioning with $2 \mathrm{~mL}$ of hexane b) injection of $1 \mathrm{~mL}$ of beeswax solution in heptane (c=5 mg/mL)

c) washing - elution of hydrocarbons from the intergrain spaces with $3 \mathrm{~mL}$ of hexane.

of hydrocarbons in beeswax. Hydrocarbons were separated on a non-polar column ZB-5HT INFERNO $20 \mathrm{~m} \times 0.18 \mathrm{~mm} \times 0.18 \mu \mathrm{m}$ (Phenomenex). Helium was used as the carrier gas, and its flow through the column was set at $1.0 \mathrm{~mL} / \mathrm{min}$. The temperature of the injector was set at $320^{\circ} \mathrm{C}$. The sample was injected in the splitless mode and under $300 \mathrm{kPa}$ (high pressure injection mode). The volume of the sample solution injected on the column was $1 \mu \mathrm{L}$. The initial temperature was set at $80^{\circ} \mathrm{C}(1 \mathrm{~min})$, and then a temperature gradient of $15^{\circ} \mathrm{C} / \mathrm{min}$ was applied until $340^{\circ} \mathrm{C}$ was reached, at which further separation of hydrocarbons was carried out. The electron source (El) was used for the ionization of the gas phase molecules. A standard ionization energy of - $70 \mathrm{eV}$ was used, and the temperature of the ion source was set at $250^{\circ} \mathrm{C}$. The interface temperature was $348^{\circ} \mathrm{C}$, and the detector temperature was $350^{\circ} \mathrm{C}$. The value of voltage on the detector was equal to the voltage obtained during autotune. The range of mass scanning was set at $50-700 \mathrm{U}$. Identification of unbranched alkanes in beeswax was conducted on the basis of comparison of the retention indexes of individual n-alkanes in the standard solution and the analyzed solution, and by comparison of the obtained mass spectra of n-alkanes with the mass spectra collected in the NIST 05 Mass Spectra Library. The qualitative analysis of alkenes and dienes was conducted on the basis of the mass spectra. When the mass spectrum of a particular compound was lacking from the library, identification was conducted on the basis of the fragmentation pathway and the presence of ions characteristic for the particular group of chemical compounds.

\section{Quantitative analysis of n-alkanes in beeswax}

The quantitative analysis of unbranched alkanes was conducted using an internal standard method. The standard mixture of n-alkanes $\left(\mathrm{C}_{8} \mathrm{H}_{18}-\mathrm{C}_{40} \mathrm{H}_{82}\right)$ was used with the internal standard, squalane $\left(\mathrm{C}_{30} \mathrm{H}_{62}\right)$. The concentration of each compound was $10 \mathrm{mg} / \mathrm{L}$.

\section{Assay validation}

The basic parameters of validation were determined, such as linearity and working range, limit of determination, repeatability and within-reproducibility, and recovery. Linearity was determined on the basis of 11 concentrations $(0.025,0.05,0.0625,0.125,0.25$, $0.625,1.25,2.5,5.0,10.0$, and $25.0 \mathrm{mg} / \mathrm{L})$ of the standard mixture of n-alkanes from $\mathrm{C}_{20} \mathrm{H}_{42}$ to $\mathrm{C}_{35} \mathrm{H}_{72}$ and 9 concentrations $(0.05,0.0625,0.125,0.25$, $0.625,1.25,2.5,5.0$, and $10.0 \mathrm{mg} / \mathrm{L}$ ) for n-alkanes from $\mathrm{C}_{36} \mathrm{H}_{74}$ to $\mathrm{C}_{40} \mathrm{H}_{82}$. Limits of determination of the method were calculated for individual n-alkanes on the basis of the calibration curve, taking the lowest concentrations for which the linearity of the method has been maintained. The repeatability and withinlaboratory reproducibility were determined based on the variability coefficients calculated for the contents of individual $n$-alkanes in the beeswax sample (with the total of n-alkanes equaling $9.24 \mathrm{~g} / 100 \mathrm{~g}$.) Two solutions of beeswax with a concentration of $0.5 \mathrm{mg} / \mathrm{mL}$ were injected into the chromatographic column to determine the recovery of n-alkanes. One solution was obtained after extraction on the SPE columns. The second one was prepared by dilution of $0.05 \mathrm{~g}$ of beeswax in $7.5 \mathrm{~mL}$ of heptane, to which $2.5 \mathrm{~mL}$ of internal standard (squalane with $\mathrm{c}$ $=400 \mathrm{mg} / \mathrm{L}$ ) was added. To obtain the same concentration as after the extraction with the SPE technique, the solution was diluted 10 times with 
heptane. Both beeswax solutions were subjected to chromatographic analysis, and the contents of individual n-alkanes were calculated.

The recovery for each determined compound after the extraction with the SPE technique was calculated from a ratio, with reference to the contents of individual alkanes in the solution without the SPE. The content of a specific n-alkane in the solution without the SPE was assumed to be $100 \%$. The recovery for the internal standard was determined on the basis of the internal standard peak heights obtained from the beeswax solution directly injected into the column (without SPE) and from the solution after SPE. The calculations were done in the same way as in the case of n-alkanes, assuming 100\% for the average internal standard height from the solution without SPE.

\section{RESULTS}

\section{Qualitative analysis of beeswax hydrocarbons}

The chromatograms of n-alkanes in the standard mixture and of beeswax hydrocarbons obtained using the GC-MS method are presented in Fig. 2 and 3 , respectively. In beeswax, long unbranched hydrocarbons (n-alkanes) containing from 20 to 35 carbon atoms in their molecules were identified (Fig. 3, Tab. 1). Apart from n-alkanes, alkenes also were found in beeswax. For certain alkenes $\left(\mathrm{C}_{23} \mathrm{H}_{46}\right.$ $\mathrm{C}_{25} \mathrm{H}_{50^{\prime}} \mathrm{C}_{27} \mathrm{H}_{54^{\prime}} \mathrm{C}_{31} \mathrm{H}_{62^{\prime}}$ and $\mathrm{C}_{35} \mathrm{H}_{70}$ ), two isomers were detected. For $\mathrm{C}_{31}, \mathrm{C}_{33^{\prime}}$ and $\mathrm{C}_{35^{\prime}}$ dienes also were identified (Fig. 3, Tab. 2).

In mass spectra of n-alkanes and alkenes, certain groups of peaks were observed when the $\mathrm{m} / \mathrm{z}$ values differed by $14 \mathrm{Da}$. The peak of the highest intensity occurred in every group. In the case of n-alkanes, the peak corresponded to the ions $\left[\mathrm{C}_{n} \mathrm{H}_{2 n+1}\right]^{+}$and occurred when $\mathrm{m} / \mathrm{z}=57,71,85$, 99, etc.; in the case of alkenes, the highest intensity had the peaks of the $\mathrm{C}_{n} \mathrm{H}_{2 n}$ and $\mathrm{C}_{n} \mathrm{H}_{2 n-1}$ ions. In addition, mass spectra of these compounds differed in molecular ions. Examples of the mass spectra of n-alkanes, alkenes, and dienes are presented in Fig. 4 - 6. The similarity index (SI) in the case of the spectra obtained for all of the beeswax n-alkanes was over $90 \%$ (Tab. 1).

\section{Quantitative analysis of $n$-alkanes in beeswax}

The total content of the n-alkanes determined in beeswax was between 9.08 and $10.86 \mathrm{~g} / 100 \mathrm{~g}$ (on average $9.81 \mathrm{~g} / 100 \mathrm{~g}$ ), with the standard deviation (SD) and the coefficient of variation (CV) amounting to 0.66 and $6.7 \%$, respectively (Tab. 3). The content of n-alkanes containing odd numbers of carbon atoms in molecules was considerably higher than the content of $n$-alkanes with even numbers of carbon atoms in molecules. The average percentage content was $6.4 \%$ for the total of even-numbered n-alkanes and $93.6 \%$ for the total of odd-numbered $n$-alkanes. The highest values were determined for the alkanes $\mathrm{C}_{27} \mathrm{H}_{56^{\prime}} \mathrm{C}_{29} \mathrm{H}_{60^{\prime}} \mathrm{C}_{31} \mathrm{H}_{64^{\prime}}$ and $\mathrm{C}_{25} \mathrm{H}_{52^{\prime}}$. The average contents of these alkanes were respectively $33.3,21.8,19.8$, and $9.7 \%$ of the total content of linear alkanes determined in the beeswax (Tab. 3). The highest variability (CV $\geq 40 \%$ ) was observed for the contents of $\mathrm{C}_{22} \mathrm{H}_{44^{\prime}} \mathrm{C}_{24} \mathrm{H}_{50^{\prime}}$ and $\mathrm{C}_{32} \mathrm{H}_{66^{\prime}}$ and the lowest sample variability was found for the contents of $\mathrm{C}_{27} \mathrm{H}_{56}(5.3 \%), \mathrm{C}_{29} \mathrm{H}_{60}(6.2 \%)$, and $\mathrm{C}_{31} \mathrm{H}_{64}(10.8 \%)$.

Based on the intensity of peaks of unsaturated hydrocarbons, $\mathrm{C}_{31} \mathrm{H}_{62}$ and $\mathrm{C}_{33} \mathrm{H}_{66}$ had the highest share of the unsaturated hydrocarbons in beeswax (Fig. 3).

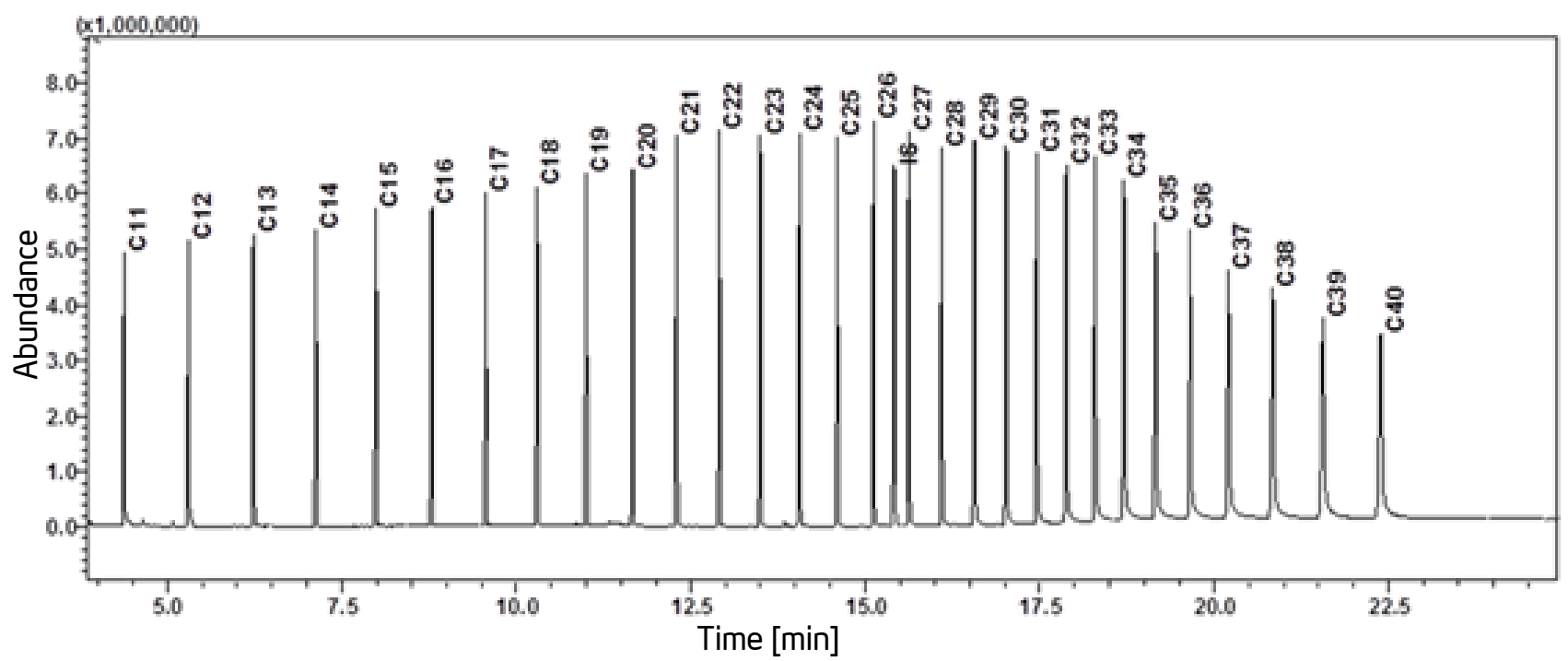

Fig. 2. Chromatogram of the standard mixture of n-alkanes $\left(\mathrm{C}_{11} \mathrm{H}_{24}-\mathrm{C}_{40} \mathrm{H}_{82}\right)$ with the internal standard (IS - $\mathrm{C}_{30} \mathrm{H}_{62}$ ) at $10 \mathrm{mg} / \mathrm{L}$. 

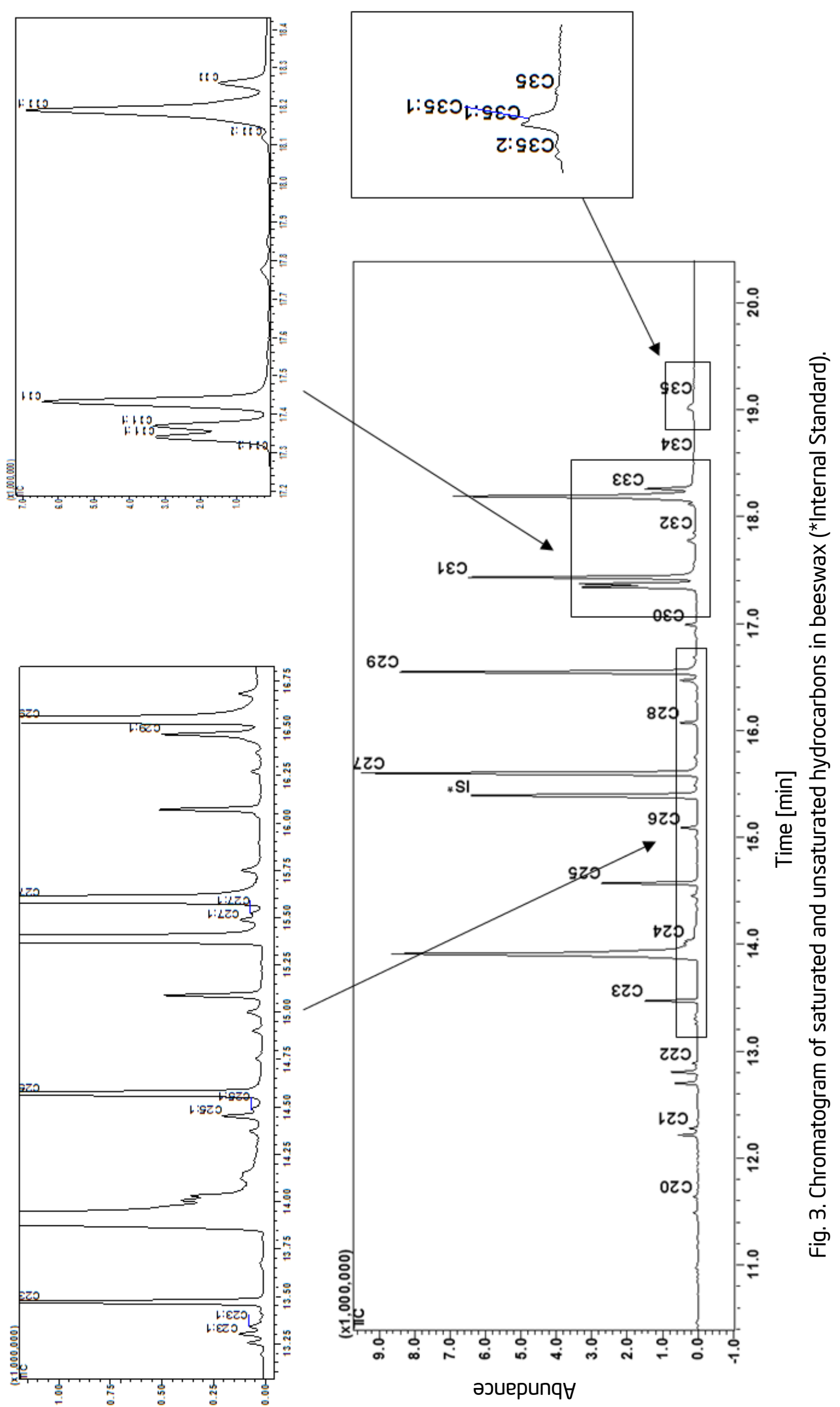
Table 1.

Homologous series of n-alkanes identified in beeswax

\begin{tabular}{cccccc}
\hline Abbreviation & $\begin{array}{c}\text { Retention time } \\
(\text { min })\end{array}$ & Compound & Formula & $\begin{array}{c}\text { Molecular } \\
\text { ion }\end{array}$ & Sl* \\
\hline C20 & 11.64 & Eicosane & $\mathrm{C}_{20} \mathrm{H}_{42}$ & $282^{\star \star}$ & 93 \\
\hline C21 & 12.28 & Heneicosane & $\mathrm{C}_{21} \mathrm{H}_{44}$ & 296 & 94 \\
\hline C22 & 12.89 & Docosane & $\mathrm{C}_{22} \mathrm{H}_{46}$ & $310^{\star \star}$ & 92 \\
\hline C23 & 13.47 & Tricosane & $\mathrm{C}_{23} \mathrm{H}_{48}$ & 324 & 94 \\
\hline C24 & 14.03 & Tetracosane & $\mathrm{C}_{24} \mathrm{H}_{50}$ & 338 & 92 \\
\hline C25 & 14.57 & Pentacosane & $\mathrm{C}_{25} \mathrm{H}_{52}$ & 352 & 94 \\
\hline C26 & 15.09 & Hexacosane & $\mathrm{C}_{26} \mathrm{H}_{54}$ & 366 & 94 \\
\hline C27 & 15.60 & Heptacosane & $\mathrm{C}_{27} \mathrm{H}_{56}$ & 380 & 94 \\
\hline C28 & 16.07 & Octacosane & $\mathrm{C}_{28} \mathrm{H}_{58}$ & 394 & 95 \\
\hline C29 & 16.55 & Nonacosane & $\mathrm{C}_{29} \mathrm{H}_{60}$ & 408 & 96 \\
\hline C30 & 16.99 & Triacontane & $\mathrm{C}_{30} \mathrm{H}_{62}$ & 422 & 92 \\
\hline C31 & 17.43 & Hentriacontane & $\mathrm{C}_{31} \mathrm{H}_{64}$ & 436 & 95 \\
\hline C32 & 17.85 & Dotriacontane & $\mathrm{C}_{32} \mathrm{H}_{66}$ & $450^{\star \star}$ & 91 \\
\hline C33 & 18.26 & Tritriacontane & $\mathrm{C}_{33} \mathrm{H}_{68}$ & 464 & 91 \\
\hline C34 & 18.59 & Tetratriacontane & $\mathrm{C}_{34} \mathrm{H}_{70}$ & $478^{\star \star}$ & $-{ }^{\star \star *}$ \\
\hline C35 & 19.11 & Pentatriacontane & $\mathrm{C}_{35} \mathrm{H}_{72}$ & $492^{\star \star}$ & $-\star \star \star$ \\
\hline
\end{tabular}

${ }^{*}$ mean similarity index of the mass spectra in comparison to mass spectra

in the NIST 05, expressed in \%

** molecular ion not observed

***identification on the basis of retention time, fragmentation pathway,

and ion peak characteristic for n-alkanes

Table 2.

Unsaturated hydrocarbons (alkenes and dienes) identified in beeswax

\begin{tabular}{ccccc}
\hline Abbreviation & Retention time (min) & Compound & Formula & Molecular ion \\
\hline C23:1* & 13.30 & Tricosene & $\mathrm{C}_{23} \mathrm{H}_{46}$ & 322 \\
\hline C23:1 & 13.34 & Tricosene & $\mathrm{C}_{23} \mathrm{H}_{46}$ & 322 \\
\hline C25:1 & 14.45 & Pentacosene & $\mathrm{C}_{25} \mathrm{H}_{50}$ & 350 \\
\hline C25:1 & 14.49 & Pentacosene & $\mathrm{C}_{25} \mathrm{H}_{50}$ & 350 \\
\hline C27:1 & 15.49 & Heptacosene & $\mathrm{C}_{27} \mathrm{H}_{54}$ & 378 \\
\hline C27:1 & 15.52 & Heptacosene & $\mathrm{C}_{27} \mathrm{H}_{54}$ & 378 \\
\hline C29:1 & 16.47 & Nonacosene & $\mathrm{C}_{29} \mathrm{H}_{58}$ & 406 \\
\hline C31:2* & 17.30 & Hentriacontadiene & $\mathrm{C}_{31} \mathrm{H}_{60}$ & 432 \\
\hline C31:1 & 17.34 & Hentriacontene & $\mathrm{C}_{31} \mathrm{H}_{62}$ & 434 \\
\hline C31:1 & 17.37 & Hentriacontene & $\mathrm{C}_{31} \mathrm{H}_{62}$ & 434 \\
\hline C33:2 & 18.12 & Tritriacontadiene & $\mathrm{C}_{33} \mathrm{H}_{64}$ & 460 \\
\hline C33:1 & 18.19 & Tritriacontene & $\mathrm{C}_{33} \mathrm{H}_{66}$ & 462 \\
\hline C35:2 & 18.91 & Pentatriacontadiene & $\mathrm{C}_{35} \mathrm{H}_{68}$ & 488 \\
\hline C35:1 & 19.01 & Pentatriacontene & $\mathrm{C}_{35} \mathrm{H}_{70}$ & 490 \\
\hline C35:1 & 19.03 & Pentatriacontene & $\mathrm{C}_{35} \mathrm{H}_{70}$ & 490 \\
\hline
\end{tabular}

${ }^{\star} 1 ; 2$ - number of double bonds in the molecule

** incomplete name of compound; does not include the location of the double bond 


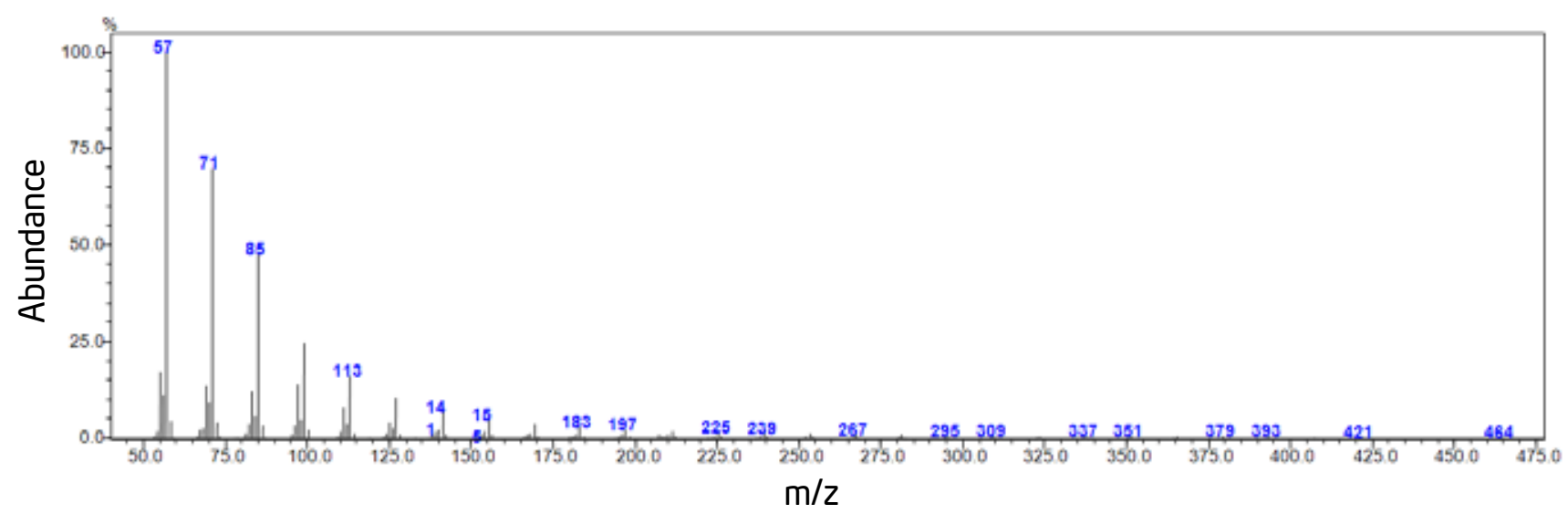

Fig. 4. Electron impact spectrum of tritriacontane $\left(\mathrm{C}_{33} \mathrm{H}_{68}\right)$ with molecular ion of $\mathrm{m} / \mathrm{z}=464$.

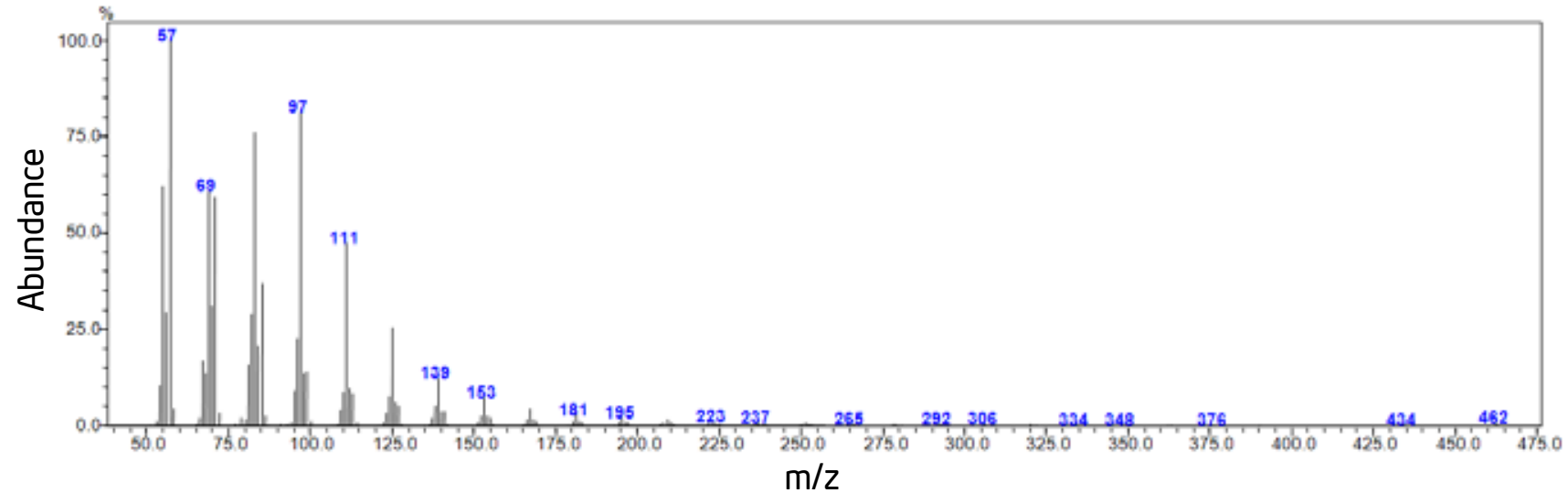

Fig. 5. Electron impact spectrum of tritriacontene $\left(\mathrm{C}_{33} \mathrm{H}_{66}\right)$ with molecular ion of $\mathrm{m} / \mathrm{z}=462$.

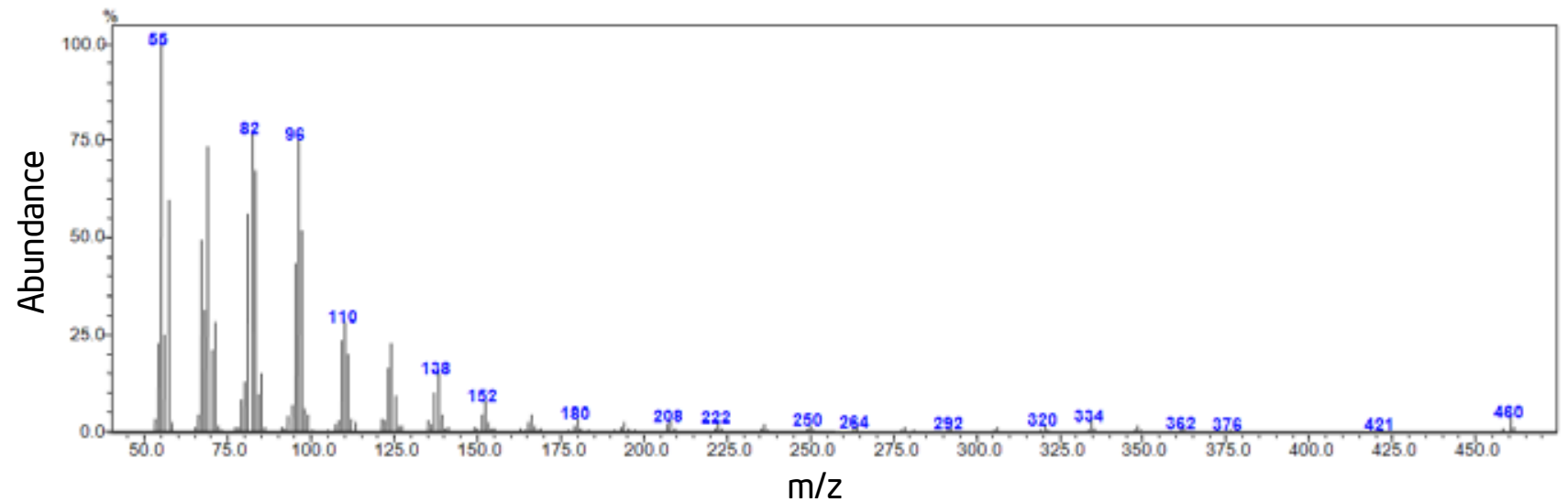

Fig. 6. Electron impact spectrum of tritriacontadiene $\left(\mathrm{C}_{33} \mathrm{H}_{64}\right)$ with molecular ion of $\mathrm{m} / \mathrm{z}=460$.

Validation results of the method for determining n-alkanes in beeswax

For all of the identified compounds, satisfactory ( $\geq 0.997)$ coefficients of correlation in the method's working range determined for individual n-alkanes were obtained (Tab. 4). Limits of determination of the method were defined as follows for each alkane: $0.005 \mathrm{~g} / 100 \mathrm{~g}$ (for alkanes from $\mathrm{C}_{20} \mathrm{H}_{42}$ to $\mathrm{C}_{30} \mathrm{H}_{62}$ ), $0.01 \mathrm{~g} / 100 \mathrm{~g}$ (for $\mathrm{C}_{31} \mathrm{H}_{64}$ and $\mathrm{C}_{32} \mathrm{H}_{66}$ ), $0.0125 \mathrm{~g} / 100 \mathrm{~g}$ (for $\mathrm{C}_{33} \mathrm{H}_{68}$ ), $0.025 \mathrm{~g} / 100 \mathrm{~g}$ (for alkanes from $\mathrm{C}_{34} \mathrm{H}_{70}$ to $\mathrm{C}_{38} \mathrm{H}_{78}$ ), and $0.05 \mathrm{~g} / 100 \mathrm{~g}$ (for $\mathrm{C}_{39} \mathrm{H}_{80}$ and $\mathrm{C}_{40} \mathrm{H}_{82}$ ). The results obtained for the repeatability and within-laboratory reproducibility are shown in Table
5. The average coefficients of variation under the conditions of repeatability and within-laboratory reproducibility were $2.04 \%$ and $3.98 \%$, respectively (Tab. 5). The results obtained for the recovery of individual n-alkanes and for the total n-alkanes in the beeswax are presented in Table 6. The highest recovery (over $100 \%$ ) was obtained for $\mathrm{C}_{20} \mathrm{H}_{42^{\prime}} \mathrm{C}_{27} \mathrm{H}_{56^{\prime}}$ $\mathrm{C}_{29} \mathrm{H}_{60}$ and $\mathrm{C}_{32} \mathrm{H}_{66}$ and for the total n-alkanes. The lowest recovery was obtained for $\mathrm{C}_{22} \mathrm{H}_{46}(94.4 \%)$. The recovery for the internal standard $\left(\mathrm{C}_{30} \mathrm{H}_{62}\right)$ was $96.6 \%$. 
Table 3.

Contents of n-alkanes $(\mathrm{g} / 100 \mathrm{~g})$ determined in beeswax $(\mathrm{n}=7)$

\begin{tabular}{|c|c|c|c|}
\hline $\begin{array}{c}\text { Formula of } \\
\text { n-alkane }\end{array}$ & Min - Max & Mean \pm SD & CV (\%) \\
\hline $\mathrm{H}_{42}$ & $0.02-0.05$ & $0.03 \pm 0.01$ & 29.8 \\
\hline $\mathrm{C}_{21} \mathrm{H}_{44}$ & $0.04-0.11$ & $0.07 \pm 0.02$ & 33.6 \\
\hline $\mathrm{C}_{22} \mathrm{H}_{46}$ & $0.03-0.09$ & $0.05 \pm 0.02$ & 46.9 \\
\hline $\mathrm{H}_{48}$ & $0.23-0.43$ & $0.29 \pm 0.07$ & 23.8 \\
\hline & $0.04-0.12$ & $0.08 \pm 0.04$ & 44.5 \\
\hline $\mathrm{C}_{25} \mathrm{H}_{52}$ & $0.75-1.12$ & $0.95 \pm 0.18$ & 18.5 \\
\hline $\mathrm{C}_{26} \mathrm{H}_{54}$ & $0.10-0.22$ & $0.15 \pm 0.04$ & 29.3 \\
\hline $\mathrm{C}_{27} \mathrm{H}_{56}$ & $2.98-3.47$ & $3.27 \pm 0.18$ & 5.3 \\
\hline & $0.08-0.18$ & $0.12 \pm 0.03$ & 28.5 \\
\hline $\mathrm{C}_{29} \mathrm{H}_{60}$ & $1.99-2.35$ & $2.14 \pm 0.13$ & 6.2 \\
\hline $\mathrm{C}_{30} \mathrm{H}_{62}$ & $0.08-0.20$ & $0.12 \pm 0.04$ & 31.8 \\
\hline $\mathrm{C}_{31} \mathrm{H}_{64}$ & $1.66-2.28$ & $1.94 \pm 0.21$ & 10.8 \\
\hline $\mathrm{C}_{32} \mathrm{H}_{66}$ & $0.04-0.12$ & $0.07 \pm 0.03$ & 44.0 \\
\hline $\mathrm{C}_{33} \mathrm{H}_{68}$ & $0.39-0.65$ & $0.50 \pm 0.08$ & 16.8 \\
\hline $\mathrm{C}_{34} \mathrm{H}_{70}$ & $<0.025^{\star}-0.03$ & - & - \\
\hline $\mathrm{C}_{35} \mathrm{H}_{72}$ & $<0.025^{\star}-0.03$ & - & - \\
\hline Total & $9.08-10.86$ & $9.81 \pm 0.66$ & 6.7 \\
\hline
\end{tabular}

Table 4.

Correlation coefficients and method's working range ( $\mathrm{g} / 100 \mathrm{~g}$ ) for n-alkanes ( $\mathrm{n}=6$ )

\begin{tabular}{ccccc}
\hline Formula of & \multicolumn{2}{c}{ Correlation coefficients (r) } & Working \\
\cline { 2 - 4 } n-alkane & Min & Max & Mean & range \\
\hline $\mathrm{C}_{20} \mathrm{H}_{42}$ & 0.9968 & 0.9984 & 0.9972 & $0.005-5$ \\
\hline $\mathrm{C}_{21} \mathrm{H}_{44}$ & 0.9962 & 0.9981 & 0.9974 & $0.005-5$ \\
\hline $\mathrm{C}_{22} \mathrm{H}_{46}$ & 0.9963 & 0.9983 & 0.9971 & $0.005-5$ \\
\hline $\mathrm{C}_{23} \mathrm{H}_{48}$ & 0.9965 & 0.9983 & 0.9972 & $0.005-5$ \\
\hline $\mathrm{C}_{24} \mathrm{H}_{50}$ & 0.9964 & 0.9978 & 0.9969 & $0.005-5$ \\
\hline $\mathrm{C}_{25} \mathrm{H}_{52}$ & 0.9961 & 0.9978 & 0.9970 & $0.005-5$ \\
\hline $\mathrm{C}_{26} \mathrm{H}_{54}$ & 0.9962 & 0.9977 & 0.9974 & $0.005-5$ \\
\hline $\mathrm{C}_{27} \mathrm{H}_{56}$ & 0.9961 & 0.9973 & 0.9968 & $0.005-5$ \\
\hline $\mathrm{C}_{28} \mathrm{H}_{58}$ & 0.9970 & 0.9981 & 0.9974 & $0.005-5$ \\
\hline $\mathrm{C}_{29} \mathrm{H}_{60}$ & 0.9978 & 0.9982 & 0.9980 & $0.005-5$ \\
\hline $\mathrm{C}_{30} \mathrm{H}_{62}$ & 0.9980 & 0.9985 & 0.9982 & $0.005-5$ \\
\hline $\mathrm{C}_{31} \mathrm{H}_{64}$ & 0.9981 & 0.9989 & 0.9983 & $0.01-5$ \\
\hline $\mathrm{C}_{32} \mathrm{H}_{66}$ & 0.9976 & 0.9993 & 0.9986 & $0.01-5$ \\
\hline $\mathrm{C}_{33} \mathrm{H}_{68}$ & 0.9981 & 0.9992 & 0.9988 & $0.0125-5$ \\
\hline $\mathrm{C}_{34} \mathrm{H}_{70}$ & 0.9983 & 0.9995 & 0.9990 & $0.025-5$ \\
\hline $\mathrm{C}_{35} \mathrm{H}_{72}$ & 0.9985 & 0.9999 & 0.9992 & $0.025-5$ \\
\hline $\mathrm{C}_{36} \mathrm{H}_{74}$ & 0.9967 & 0.9994 & 0.9989 & $0.025-2$ \\
\hline $\mathrm{C}_{37} \mathrm{H}_{76}$ & 0.9978 & 0.9996 & 0.9992 & $0.025-2$ \\
\hline $\mathrm{C}_{38} \mathrm{H}_{78}$ & 0.9991 & 0.9998 & 0.9993 & $0.025-2$ \\
\hline $\mathrm{C}_{39} \mathrm{H}_{80}$ & 0.9978 & 0.9996 & 0.9982 & $0.05-2$ \\
\hline $\mathrm{C}_{40} \mathrm{H}_{82}$ & 0.9976 & 0.9988 & 0.9979 & $0.05-2$ \\
\hline
\end{tabular}


Table 5.

Repeatability and within-laboratory reproducibility for determination of n-alkanes in beeswax

\begin{tabular}{ccc}
\hline $\begin{array}{c}\text { Formula of } \\
n \text {-alkane }\end{array}$ & $\begin{array}{c}\text { Coefficients of variation (\%) } \\
\text { Repeatability } \\
(n=5)\end{array}$ & $\begin{array}{c}\text { Reproducibility } \\
(n=10)\end{array}$ \\
\hline $\mathrm{C}_{20} \mathrm{H}_{42}$ & 4.13 & 13.70 \\
\hline $\mathrm{C}_{21} \mathrm{H}_{44}$ & 2.24 & 5.82 \\
\hline $\mathrm{C}_{22} \mathrm{H}_{46}$ & 4.64 & 8.75 \\
\hline $\mathrm{C}_{23} \mathrm{H}_{48}$ & 1.92 & 5.05 \\
\hline $\mathrm{C}_{24} \mathrm{H}_{50}$ & 4.80 & 12.94 \\
\hline $\mathrm{C}_{25} \mathrm{H}_{52}$ & 1.11 & 4.07 \\
\hline $\mathrm{C}_{26} \mathrm{H}_{54}$ & 2.26 & 5.93 \\
\hline $\mathrm{IS}_{27}$ & 2.43 & 4.41 \\
\hline $\mathrm{C}_{27} \mathrm{H}_{56}$ & 1.18 & 3.60 \\
\hline $\mathrm{C}_{28} \mathrm{H}_{58}$ & 2.66 & 5.11 \\
\hline $\mathrm{C}_{29} \mathrm{H}_{60}$ & 1.19 & 3.87 \\
\hline $\mathrm{C}_{30} \mathrm{H}_{62}$ & 3.45 & 6.33 \\
\hline $\mathrm{C}_{31} \mathrm{H}_{64}$ & 2.45 & 3.68 \\
\hline $\mathrm{C}_{32} \mathrm{H}_{66}$ & 3.66 & 12.62 \\
\hline $\mathrm{C}_{33} \mathrm{H}_{68}$ & 2.40 & 4.24 \\
\hline $\mathrm{C}_{34} \mathrm{H}_{70}$ & $\mathrm{nc}$ & $\mathrm{nc}$ \\
\hline $\mathrm{C}_{35} \mathrm{H}_{72}$ & $\mathrm{nc}$ & $\mathrm{nc}$ \\
\hline Total & 2.04 & 3.98 \\
\hline${ }^{*}$ not calculated, the determined values for those \\
alkanes were below limit of determination $^{*}$
\end{tabular}

\section{DISCUSSION}

Gas chromatography with mass detector (GC-MS) was used to develop a method for identification of beeswax hydrocarbons and for quantitative determination of n-alkanes, the biggest group of hydrocarbons occurring in beeswax. In previous related reports (Aichholz and Lorbeer, 2000; Jimenez et al., 2004; Serra Bonvehi and Ornantes Bermejo, 2012; Maia and Nunes, 2013), the GC-MS technique was used mainly for qualitative analysis of beeswax hydrocarbons; however, detailed quantitative analysis of these compounds was not conducted, and only their percentage shares were determined.

Satisfactory chromatographic separation of n-alkanes and for some alkenes and dienes was obtained on the ZB-5HT INFERNO $(20 \mathrm{~m} \times 0.18 \mathrm{~mm}$ $\times 0.18 \mu \mathrm{m})$ column with adequately set separation parameters (temperature and carrier gas flow, among others). Similar conditions of chromatographic separation were used by Jimenez et al. (2004) and Maia and Nunes (2013); however, they employed a longer $(30 \mathrm{~m})$ column and different temperature program. These differences and the lack of the preliminary stage of separation of the hydrocarbon

Recovery (\%) of the individual n-alkanes and internal standard (IS) in beeswax ( $n=3)$ after SPE

\begin{tabular}{|c|c|c|c|}
\hline \multirow{2}{*}{$\begin{array}{c}\text { Formula } \\
\text { of } \\
\text { n-alkanes }\end{array}$} & \multicolumn{2}{|c|}{$\begin{array}{c}\text { Content of } \\
\text { n-alkanes }(\mathrm{g} / 100 \mathrm{~g})\end{array}$} & \multirow{2}{*}{ Recovery } \\
\hline & $\begin{array}{l}\text { without } \\
\text { SPE }\end{array}$ & SPE & \\
\hline $\mathrm{H}_{42}$ & 0.034 & 0.036 & 105.9 \\
\hline & 0.045 & 0.043 & 95.6 \\
\hline & 0.036 & 0.034 & 94.4 \\
\hline $\mathrm{H}_{48}$ & 0.228 & 0.224 & 98.2 \\
\hline & 0.067 & 0.064 & 95.5 \\
\hline & 0.823 & 0.806 & 97.9 \\
\hline $\mathrm{C}_{26} \mathrm{H}_{54}$ & 0.127 & 0.123 & 96.9 \\
\hline IS & - & - & 96.6 \\
\hline $\mathrm{C}_{27} \mathrm{H}_{56}$ & 3.411 & 3.448 & 101.1 \\
\hline $\mathrm{C}_{28} \mathrm{H}_{58}$ & 0.097 & 0.094 & 96.9 \\
\hline $\mathrm{C}_{29} \mathrm{H}_{60}$ & 2.015 & 2.115 & 105.0 \\
\hline $\mathrm{C}_{30} \mathrm{H}_{62}$ & 0.075 & 0.074 & 98.7 \\
\hline $\mathrm{C}_{31} \mathrm{H}_{64}$ & 1.779 & 1.727 & 97.1 \\
\hline $\mathrm{C}_{32} \mathrm{H}_{66}$ & 0.034 & 0.035 & 102.9 \\
\hline $\mathrm{C}_{33} \mathrm{H}_{68}$ & 0.450 & 0.444 & 98.7 \\
\hline $\mathrm{C}_{34} \mathrm{H}_{70}$ & $<0.025^{\star}$ & $<0.025$ & - \\
\hline $\mathrm{C}_{35} \mathrm{H}_{72}$ & $<0.025^{\star}$ & $<0.025$ & - \\
\hline Total & 9.221 & 9.267 & 100.5 \\
\hline
\end{tabular}

fraction from the remaining beeswax compounds resulted in a much longer time of analysis in those studies.

When using the GC-MS technique in the analysis of beeswax hydrocarbon composition, the stage of sample preparation is very important and involves removing all the impurities and interfering compounds (e.g., esters). Here, for the isolation of beeswax hydrocarbons, SPE was used with columns filled with neutral aluminum oxide according to our own elaborated procedure. Applying the SPE technique allowed improved detection and increased selectivity in relation to the separated analytes. The recovery for the majority of the n-alkanes was over $95 \%$. The isolation of the hydrocarbon fraction allowed for a significant decrease (from 45 to about $25 \mathrm{~min}$ ) in the analysis time and substantially simplified the qualitative and quantitative analysis of the determined compounds. Using SPE at the sample preparation stage had the most significant effect for determining n-alkanes with even numbers of carbon atoms in a molecule, which are difficult to detect. In the case of determination of hydrocarbons without the preliminary purification of a sample, with other compounds of beeswax, the n-alkanes peaks, 
especially even-numbered n-alkanes, overlapped with the peaks of esters. This overlap could have led to inaccurate results of the quantitative analysis. Jimenez et al. (2004) also indicated this problem connected to peak overlap.

Moreover, the method reported here for quantitative analysis of n-alkanes in beeswax with GC-MS is characterized by satisfactory repeatability and within-laboratory reproducibility. For all of the identified compounds, satisfactory ( 20.997$)$ coefficients of correlation were obtained in the working ranges of the method determined for individual n-alkanes.

The results of the GC-MS analysis showed that the dominant group of the beeswax hydrocarbons is n-alkanes containing from 20 to 35 carbon atoms in their molecules. These results are in line with those previously reported by other authors, although slightly different lengths of the carbon chains were indicated (White et al., 1960; Downing et al., 1961; Aichholz and Lorbeer, 1999, 2000; jimenez et al., 2004; Serra Bonvehi and Ornantes Bermejo, 2012). The differences in the qualitative composition of the beeswax reported by different authors are undoubtedly caused by various limits of detection of these compounds and by the manner of beeswax sample preparation for the analysis. In the studies here presented, it was impossible to identify alkanes containing fewer than 20 carbon atoms in the molecule because of the extraction of hydrocarbons with the SPE technique employed at the stage of the sample preparation for the chromatographic separation. The chromatographic analysis of the "blank" beeswax sample showed the presence of peaks originating from the impurities eluted from the SPE column with the same retention times as peaks originating from these alkanes. Hence, it was impossible to establish whether the peaks originated from alkanes occurring in beeswax or from the impurities.

Using the elaborated GC-MS method resulted in the identification of saturated hydrocarbons (n-alkanes) and also alkenes and dienes. Other authors have reported the presence of these unsaturated hydrocarbons in beeswax (Streibl et al., 1966; Serra Bonvehi, 1988; Giumanini et al., 1995; Aichholz and Lorbeer, 1999, 2000; Jimenez et al., 2004, 2007; Serra Bonvehi and Ornantes Bermejo, 2012). Streibl et al. (1966) observed that the highest share, similar to the alkanes, had alkenes with odd numbers of carbon atoms in their molecules (especially $\mathrm{C}_{31} \mathrm{H}_{62}$ and $\mathrm{C}_{33} \mathrm{H}_{66}$ ). They also indicated that these hydrocarbons occur mainly in a form of the cis isomers while locating the double bond at $\mathrm{C}_{10}$ in most of the alkenes. The results of our studies did not allow identification of the double bonds in the molecules of the unsaturated hydrocarbons because of some limitations of the equipment. When using the mass spectrometer with single quadrupole, it is impossible to locate the unsaturated bonds and to fully identify the isomers. Because of the lack of standards for the unsaturated hydrocarbons, it was also impossible to perform quantitative analysis. However, based on the intensity of the peaks, it was determined that similar to the reports of Streibl et al. (1966), $\mathrm{C}_{31} \mathrm{H}_{62}$ and $\mathrm{C}_{33} \mathrm{H}_{66}$ had the highest share. Aichholz and Lorbeer (1999, 2000) identified only these two alkenes in the wax secreted by $A$. mellifera, but these authors, as well as Serra Bonvehi and Ornantes Bermejo (2012), found no dienes in A.mellifera beeswax.

The results obtained here of the qualitative analysis of the unsaturated hydrocarbons are similar to those of Jimenez et al. (2004, 2007). Differences concern the amount of identified isomers and result from different limits of detection, as with the qualitative analysis of the saturated hydrocarbons. Jimenez et al. $(2004,2007)$ identified two isomers for each of $\mathrm{C}_{29} \mathrm{H}_{58}$ and $\mathrm{C}_{33} \mathrm{H}_{66}$ while the results of our studies and reports by Serra Bonvehi and Ornantes Bermejo (2012) showed the presence of single alkenes. Additionally, Jimenez et al. (2004, 2007) observed $\mathrm{C}_{21} \mathrm{H}_{42}$ (single isomer), $\mathrm{C}_{30} \mathrm{H}_{60}$ (two isomers), $\mathrm{C}_{32} \mathrm{H}_{64}$ (one isomer), and dienes $\mathrm{C}_{23} \mathrm{H}_{44}$ and $\mathrm{C}_{25} \mathrm{H}_{48}$. They did not, however, find $\mathrm{C}_{35} \mathrm{H}_{68}$, which was identified in the present work.

In the present studies, the quantitative analysis of $n$-alkanes of beeswax using the internal standard method was also performed. Our results of the $n$-alkane content in the beeswax are hard to compare with published data, though. Aichholz and Lorbeer $(1999,2000)$ estimated the percentage share of individual alkanes based on the ratio of the certain peak area to the sum of the areas of peaks obtained for all of the analyzed compounds (the method of internal normalization). The total alkanes in wax originating from $A$. mellifera calculated in this way were slightly higher than the maximum content of all alkanes calculated in the current work. The percentage share of individual alkanes reported by jimenez et al. $(2004,2006,2007)$ and Serra Bonvehi and Ornantes Bermejo (2012) is also hard to compare with the results of our studies because of different calculation methods (these were not the typical quantitative analyses with the usage of standards) as well as different analytical methods. Jimenez et al. (2004) determined the 
content of individual compounds according to the intensity of peaks obtained with the GC-MS method. In their later studies (Jimenez et al. 2006, 2007; Serra Bonvehi and Ornantes Bermejo, 2012), these groups used the technique of gas chromatography with FID detector for the quantitative analysis of the beeswax hydrocarbons. For the percentage share of individual alkanes, they calculated based on the ratio of certain peak area to the area of the peak obtained for the internal standard. Thus, they assumed that the signal coming from the detector for all of the determined compounds was the same as for the internal standard. Our studies indicate that this is not true, which is why we used the internal standard method for quantitative determinations, with squalane as the internal standard, and a standard mixture of all identified compounds. The total content of hydrocarbons estimated by Serra Bonvehi and Ornantes Bermejo (2012) was higher in comparison with the results obtained in our study. The higher content resulted from the above-mentioned differences in calculations and the content of alkenes that were added to the total of hydrocarbons. The results of White et al. (1960) were also higher than those reported here because, similar to the results of Serra Bonvehi and Ornantes Bermejo (2012), they relate to the total of all hydrocarbons occurring in beeswax, while in the current study only unbranched alkanes were determined quantitatively.

In our studies, the content of unbranched n-alkanes containing an odd number of carbon atoms was significantly higher in comparison to the content of n-alkanes with an even number of carbon atoms. Significant dominance of the odd-numbered alkanes over the even-numbered alkanes in beeswax already was reported in the first chromatographic studies of beeswax (White et al., 1960; Streibl et al., 1966). Those findings were also confirmed by the most recent reports (Aichholz and Lorbeer, 1999, 2000; jimenez et al., 2004, 2006, 2007; Serra Bonvehi and Ornantes Bermejo, 2012). The discrepancy in the quantitative results obtained by different authors, as already mentioned before, follows in the first place from the method of calculation, as clearly shown when comparing the contents of individual compounds. The manner of sample preparation for the chromatographic analysis also substantially influenced the final results. In our studies, for the purification of the sample and isolation of the hydrocarbon fraction from beeswax, the SPE technique was used, while other authors (Aichholz and Lorbeer, 1999, 2000; Jimenez et al., 2007; Serra Bonvehi and Ornantes Bermejo, 2012) determined the hydro- carbons along with other compounds of beeswax. During the current studies, it was observed that if the hydrocarbons were analyzed with other beeswax compounds, the results of the quantitative analysis could be overestimated because the peaks originating from alkanes (especially even-numbered alkanes) can overlap with the ester peaks. As noted, jimenez et al. (2004) have previously mentioned this problem.

\section{CONCLUSIONS}

The elaborated method for hydrocarbon determination using a GC-MS technique allows identification of beeswax hydrocarbons (alkanes, alkenes, and dienes) and quantification of unbranched alkanes (n-alkanes). Extraction of hydrocarbons from beeswax using the SPE technique with columns filled with neutral aluminum oxide facilitates the qualitative and quantitative analysis of these compounds.

The largest group of beeswax hydrocarbons is the n-alkanes, containing from 20 to 35 carbon atoms. The percentage share of the odd-numbered n-alkanes is significantly higher in comparison to even-numbered alkanes and amounts to about $94 \%$. In addition to the saturated hydrocarbons, unsaturated hydrocarbons such as alkenes and dienes occur in beeswax.

\section{ACKNOWLEDGEMENTS}

This research was supported in part by the Ministry of Science and Higher Education of Poland, COST ACTIONFA0803, grant number 527/N-COST/2009/0. The authors thank colleagues from other Departments of Apicultural Division, Research Institute of Horticulture for beeswax samples.

\section{REFERENCES}

Aichholz R., Lorbeer E. (1996) Use of methoxy-terminated poly (diphenyl $1 \mathrm{H}, 1 \mathrm{H}, 2 \mathrm{H}, 2 \mathrm{H}$ - perfluorodecylmethyl) siloxane as stationary-phase for high-temperature capillary gas-chromatography and its application in the analysis of beeswax. Journal of Microcolumn Separation 8(8): 553-559. DOl: 10.1002/(SICI)1520667X(1996)8:8<553:.AID-MCS5>3.0.C0;2-0/pdf

Aichholz R., Lorbeer E. (1999) Investigation of combwax of honeybees with high-temperature gas chromatography and high - temperature gas chromatography - chemical ionization mass spectrometry. I - High-temperature gas chromatography. Journal of Chromatography A 855: 601-615. DOl: 10.1016/S0021-9673(99)00725-6 
Aichholz R., Lorbeer E. (2000) Investigation of combwax of honeybees with high-temperature gas chromatography and high - temperature gas chromatography - chemical ionization mass spectrometry. II - High-temperature gas chromatography - chemical ionization mass spectrometry. Journal of Chromatography A 883: 75-88. DOl: 10.1016/S0021-9673(00)00386-1

Bernal J. L., Jimenez J. J., del Nozal M. J., Toribio L., Martin M. T. (2005) Physico-chemical parameters for the characterization of pure beeswax and detection of adulterations. European Journal of Lipid Science and Technology 107(3): 158-166. DOl: 10.1002/ejlt.200401 105

Bogdanov S. (2004) Beeswax: quality issues today. Bee World 85(3): 46-50.

Curyło J., Ignaszewska T. (1969) Porównanie dwu metod oznaczania węglowodorów w wosku pszczelim. Pszczelnicze Zeszyty Naukowe 13(1-2-3): 137-141.

Curyło J., Zalewski W. (1957a) Charakterystyka krajowego wosku pszczelego z naturalnych nieczerwionych plastrów oraz charakterystyka węglowodorów wydzielonych z niego przy pomocy chromatografii. Pszczelnicze Zeszyty Naukowe 1(3): 105-117.

Curyło J., Zalewski W. (1957b) Ilościowa metoda oznaczania parafiną i cerezyną. Pszczelnicze Zeszyty Naukowe 1(3): 118-128.

DGF-M-V-6 (1957) DGF - Einheitsmethoden - Abteilung M - Wachse. German Standard -Beeswax. 29 pp. Available at: http://www.dgfett.de/methods/inhaltsverzeichnis.pdf

Downing T. D., Kranz Z. H., Lamberton J. A., Murray K. E., Redcliffe A. H. (1961) Studies in waxes. XVIII. Beeswax: A spectroscopic and gas chromatographic examination. Australian Journal of Chemistry 14: 253-263.

EFSA (2007) Beeswax (E 901) as a glazing agent and as carrier for flavours. The EFSA Journal 615: 1-28.

Fuschs W., de Jong A. (1954) Chromatographische Zerlegung von Bienenwachs. Fette-Seifen-Anstrichmittel 56(4): 218-220.

Giumanini A. G., Verardo G., Strazzolini P., Hepburn H. R. (1995) Rapid detection of high-molecular-mass dienes in beeswax. Journal of Chromatography A 704: 224-227. DOl: 10.1016/0021-9673(95)00145-D jimenez J. J., Bernal J. L., Aumente S., Toribio L., Bernal Jr. J. (2003) Quality assurance of commercial beeswax II. Gas chromatography - electron impact ionization mass spectrometry of alcohols and acids. Journal of Chromatography A 1007: 101-116. DOl: 10.1016/S00219673(03)00962-2

Jimenez J. J., Bernal J. L., del Nozal M. J., Martin M. T., Bernal J. (2006) Sample preparation methods for beeswax characterization by gas chromatography with flame ionization. Journal of Chromatography A 1 129: 262-272. DOl: 10.1016/j.chroma.2006.06.098

Jimenez J. J., Bernal J. L., del Nozal M. J., Martin M. T., Toribio L. (2009) Identification of adulterants added to beeswax: Estimation of detectable minimum percentages. European Journal of Lipid Science and Technology 111 : 902-91 1. DOl: 10.1002/ejlt.200800263

Jimenez J. J., Bernal J. L., del Nozal M. J., Toribio L., Bernal J. (2007) Detection of beeswax adulterations using concentration guide-values. European Journal of Lipid Science and Technology 109: 682-690. DOl: 10.1002/ ejlt.200600308

Jimenez J. J., Bernal J. L., Aumente S., del Nozal., Martin M. T., Bernal Jr. .. (2004) Quality assurance of commercial beeswax - Part I. Gas chromatography - electron impact ionization mass spectrometry of hydrocarbons and monoesters. Journal of Chromatography A 1024: 147-154. DOl: 10.1016/j.chroma.2003.10.063

Maia M., Nunes F. M. (2013) Authentication of beeswax (Apis mellifera) by high-temperature gas chromatography and chemometric analysis. Food Chemistry 136: 961-968. D0l: 10.1016/j.foodchem.2012.09.003

PN-R-78890 (1996) Wosk Pszczeli. Polski Komitet Normalizacyjny. Wydawnictwo Normalizacyjne "Alfa". Warszawa

Poncini L., Poncini A., Prakash D. (1993) The effects of washing on the fluorescent impurities and chemical properties of Fijian beeswax from Apis mellifera L. Apiacta 2: 42-51.

Serra Bonvehi J. (1988) Estudio de la composición de la cera de abejas (Apis mellifera L.) española. Grasas y Aceites 39 Fasc. 6: 334-342.

Serra Bonvehi J. (1990) Estudio de la adulteracion de la cera de abejas. Grasas y Aceites 41: 69-72. 


\section{J. APIC. SCL. YOL. 58 NOV. 12014}

Serra Bonvehi J., Ornantes Bermejo F. J. (2012) Detection of adulterated commercial Spanish beeswax. Food Chemistry 132: 642-648. D0l: 10.1016/j.foodchem.201 1.10.104

Serra Bonvehi J., Cañas Lloria S., Gomez Pajuelo (1989) Caracteristicas fisico-quimicas de la cera de abejas producida en Espana. Alimentacion, equipos y tecnologia 5-6: 213-216.

Skowronek W. (1973) Rozwój gruczołów woskowych u różnych ras pszczoły miodnej. Pszczelnicze Zeszyty Naukowe 17: 1-9.

Sprengler G., Wöllner E. (1953) Eine neue Paraffin Bestimmungsmethode von Wachsen und Wachs - Verschnitten. Fette-Seifen-Anstrichmittel 57(1): 5-8.

Sprengler G., Wöllner E. (1954) Adsorptive Trennung von Wachsen und Wachskomponenten. Fette-Seifen-Anstrichmittel 56(10): 775-784.
Streibl M., Stransky K., Sorm F. (1966) Über einige neue Kohlenwasserstoffe in Wachs der Honigbiene (Apis mellifera L.). Fette Seifen Anstrichmittel 68: 799-805.

Tulloch A. P. (1973) Factors Affecting Analytical Values of Beeswax and Detection of Adulteration. Journal of the American Oil Chemists' Society 50: 269-272.

Tulloch A. P. (1980) Beeswax - composition and analysis. Bee World 61: 47-62.

Vit P., Roldan S., Tamer E., Olivo de Acosta E., Bianchi M. (1992) Deteccion de adulteraciones en cera de abejas comercializadas en Venezuela. Revista del Instituto Nacional de Higiene Rafael Rangel 23: 23-27.

White J. W. Jr., Reader M. K., Riethof M. L.( 1960) Chromatographic Determination of Hydrocarbons in Beeswax. Journal of the Association of Official Agricultural Chemists 43: 778-780. 